\title{
Gold Mining And Socioeconomic Changes Of Coastal Communities In Buru Island Kaiely Bay District
}

\author{
Firmansyah $^{1}$, Mardiana E. Fachry ${ }^{2}$ Andi Adri Arief. ${ }^{3}$ \\ Department of Fisheries, F Marine Science and Fisheries Hasanuddin University Makassar \\ DOI: 10.29322/IJSRP.11.11.2021.p11914 \\ http://dx.doi.org/10.29322/IJSRP.11.11.2021.p11914
}

\begin{abstract}
During the existence of traditional gold mines in the bald mountain district of Teluk Kaiely, Buru Maluku province, there has been a lot of changes in the lives of the local people. The research methodology used is descriptive method with qualitative approach. data collection techniques used are interviews, observations, and literature studies. The informant in this study consisted of a fisherman, and one of the perna became a gold miner. presentation of data and verification / conclusion. the results of the study showed that the existence of gold mines on bald mountains has had an impact on the socioeconomic conditions of coastal communities. Gold mining has a negative impact on aspects of uncontrolled and alarming population displacement, the increasing incidence of conflict, and the transition of people's livelihoods from fishermen, farmers to miners.
\end{abstract}

Index Terms- Economic Change, Coastal Communities.

\section{INTRODUCTION}

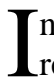
ndonesia is a country rich in natural resources. Natural resources (both renewable and nonrenewable) are essential resources for human survival. The loss or decrease in the availability of these resources will have a huge impact on the survival of mankind.

Buru regency is located between 2o $25^{\prime}-30$ 83' South latitude and $126 \mathrm{o} 08^{\prime}-127 \mathrm{o} 20$ Longitude Tiimur. Its existence in three important cities in Eastern Indonesia (Makassar, Manado/ Bitung, and Ambon) and traversed by Sea Line III (sea route which describes the main maritime route between the ports used for logistics and naval trade in the three areas above), puts Buru Regency in a strategic position.

Based on the results of previous research on the impact of baukit mining on fishermen's income on the island banuba lingga district in February 2012 by nurlida, in getting on the direct influence of mining activities on fishermen's income, where fishermen's income becomes reduced after the mining activities baukit. The main factor that resulted in their income decreased was the number of catches that decreased compared to before the baukit.

This phenomenon prompted the authors to conduct a study entitled "gold mining and socioeconomic changes of coastal communities on the island of Buru kaiely bend subdistrict"

\section{RESEARCH METHODS}

This research started in October-November 2020. This location is chosen deliberately (purposive) based on consideration that is one of the gold mining centers located. research was conducted in buru district by taking samples of fishermen in kaiely bay subdistrict

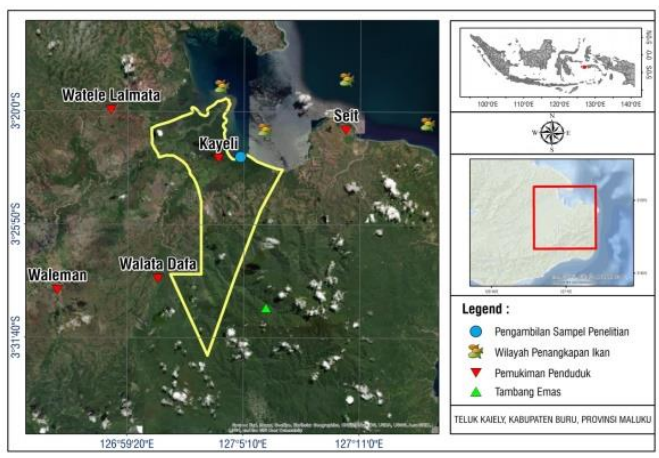

Figure 1. Research Location

To get the information needed by the author using the method of data collection hammering:

1. Field studies, namely conducting observations and direct interviews with respondents involving research objects and giving questionnaires or lists of questions in writing.

2. Literature studies to refine scientific information from books, journals and others related to the problem studied. 


\begin{tabular}{|c|c|c|c|}
\hline$\underline{\text { Variable }}$ & $\begin{array}{l}\text { Techniqu } \\
\text { e }\end{array}$ & $\begin{array}{l}\text { Instrume } \\
\text { nts }\end{array}$ & Respondents \\
\hline $\begin{array}{l}\text { History of the } \\
\text { mine }\end{array}$ & Income & $\begin{array}{l}\text { question } \\
\text { naire }\end{array}$ & $\underline{\text { Fisherman }}$ \\
\hline Level of education & $\underline{\text { Income }}$ & $\begin{array}{l}\text { question } \\
\text { naire }\end{array}$ & $\underline{\text { Fisherman }}$ \\
\hline Types of work & Income & $\begin{array}{l}\text { question } \\
\text { naire }\end{array}$ & Fisherman \\
\hline Income & Income & $\begin{array}{l}\text { question } \\
\text { naire }\end{array}$ & Fisherman \\
\hline$\underline{\text { Social conditions }}$ & Income & $\begin{array}{l}\text { question } \\
\text { naire }\end{array}$ & $\underline{\text { Fisherman }}$ \\
\hline conflict & Income & $\begin{array}{l}\text { question } \\
\text { naire }\end{array}$ & Fisherman \\
\hline Mining activities & Income & $\begin{array}{l}\text { question } \\
\text { naire }\end{array}$ & Fisherman \\
\hline
\end{tabular}

Table 1. Research Instruments

\section{$>$ Research Procedures}

This type of research is survey research while the method is descriptive analysis. Descriptive survey method is a research method that takes samples from a population and uses questionnaires as a data collection tool.

\section{$>$ Population and Samples}

The population in this study is the people on Buru Island, Kaiely Bay sampling technique used is Stratified Random Sampling, where there are strata in the population based on the type of fishing equipment.

\section{RESULTS AND DISCUSSION}

Table 2. Selling Price Based on Catch

\begin{tabular}{|l|l|l|l|}
\hline $\begin{array}{l}\text { Types of } \\
\text { fish }\end{array}$ & $\begin{array}{l}\text { Before } \\
\text { There Was a } \\
\text { Mine }\end{array}$ & $\begin{array}{l}\text { Once there's } \\
\text { a mine }\end{array}$ & $(\%)$ \\
\hline Anchovies & $5.000 / \mathrm{Kg}$ & $15.000 / \mathrm{Kg}$ & 10 \\
\hline Tuna & $6.700 / \mathrm{Kg}$ & $17.900 / \mathrm{kg}$ & 24 \\
\hline The fish & $10.000 / \mathrm{Kg}$ & $25.000 / \mathrm{kg}$ & 18 \\
\hline $\begin{array}{l}\text { Cakalang } \\
\text { Fish }\end{array}$ & $70.000 / \mathrm{Kg}$ & $160.000 / \mathrm{kg}$ & 33 \\
\hline $\begin{array}{l}\text { Laying } \\
\text { mine }\end{array}$ & $6.800 / \mathrm{Kg}$ & $15.400 / \mathrm{kg}$ & 11 \\
\hline $\begin{array}{l}\text { Mullet, } \\
\text { shrimp }\end{array}$ & $5.000 / \mathrm{Kg}$ & $15.000 / \mathrm{kg}$ & 10 \\
\hline $\begin{array}{l}\text { Mullet, } \\
\text { kwee }\end{array}$ & $9.000 / \mathrm{Kg}$ & $24.000 / \mathrm{kg}$ & 17 \\
\hline
\end{tabular}

Based on the research conducted showed that the level of income rmening, after the additional income with the process of gold mining in the bald mountain in the bay kaiyeli district buru maluku province.

Selling price of respondents before the existence of gold mining majority (5\%) income class of Rp.5,000 After gold mining, the income level of the majority of respondents shifted to the majority (10\%) rp. 15,000 . or more. This is due to the open employment opportunities and income from gold mining jobs and related sectors. The same was also discovered by Pasaribu, 2010 who conducted a study on the socioeconomic impact of gold mining in Batang Toru, Central Tapanuli, where official gold mining activities at the site open employment opportunities and increase people's income, mainly due to the multiplier effect of gold mining activities. Similarly, refles research, 2012 in West Sumatra, proved that traditional gold mining activities open employment opportunities and additional income for the community.

Socioeconomic changes of society can be measured from quantitative magnitude related to the socioeconomic aspect as well as from people's perception of the socioeconomic state of life due to programs, activities, technology and other new aspects in society (Hastuti, et al., 2004; Pasaribu, 2010and Refles, 2012).

\section{ECONOMIC CONDITIONS}

Coastal communities, are communities that have a large dependence on the potential of coastal resources, both on the potential of fisheries and dependence on other ecosystems.

In this region, most of its people live from managing coastal and marine resources, either directly or indirectly. Therefore, from the perspective of penc iannya eyes, coastal communities are composed of groups of communities as diverse as fishermen, farmers, fish traders, shop owners, as well as small and mediumsized industry players processing catches.

Kaiely Bay has several ecosystems that can make room for the survival of the people who inhabit it. One of them is mangrove forest ecosystem. The area of mangrove ecosystem on the coast of Kaiely Bay $\pm 4,588.3$ ha., making this ecosystem enough to provide hope for the coastal communities of Kaiely Bay for the utilization of the potential in it. Based on the results obtained, one of the research sites, namely Sanleko Village Subdistrict

Namlea, making the mangrove ecosystem as a place to do fishery activities, namely catching mangrove crabs using bubu fishing equipment. In addition, not a few use mangroves as firewood and building materials, although this activity greatly disrupts the balance of the ecosystem.

\section{CONCLUSIONS AND SUGGESTIONS}

\section{A. Conclusion}

$>$ Economically, there is a change experienced by the community, after the mining of gold, namely the demand for fish is higher and the income increases.

$>$ Socially the decline in fishermen's activity to sea, due to some of them switching to miners.

\section{B. Suggestion}

$>$ Capacity building of fishery extension workers.

$>$ Socialization of the laws and regulations on the governance of fisheries and coastal areas.

$>$ Socialization of the dangers of gold processed waste is linked to the balance of aquatic ecosystems and the existence of potential fish resources. 


\section{REFERENCES}

[1] Directorate General of Cultivation. 2005. Profile of Indonesian Seaweed. Directorate of Aquaculture. Department of Fisheries and Marine Affairs. Jakarta.

[2] Dwidjoseputro, D. 1994. Introduction to Plant Physiology. PT Gramedia Pustaka Utama, Jakarta.

[3] Plankton Study on Fisheries and Marine Sciences. Undip Issuing Agency, Semarang.

[4] Tangguda, S., D. Arfiati, \&A. W. Ekawati. 2015. Utilization of Solid Waste from White Shrimp (Litopenaeus vannamei) Farm on The Growth and Chlorophyll Content in Chlorella sp. Journal of Life Sci. Biomed 5 (3), 8185

[5] Fisheries and Marine Service of Maluku Province. (2007). Yearbook of Fisheries Statistics of Maluku Province in 2007. Fisheries and Marine Service of Maluku Province.

[6] Nanlohy, H., and Christianty, (2007). Level of Welfare of Pole and Line Owner Fishermen in Buru Regency, Maluku Province. Report of Young Lecturers Research Results.

[7] Nurani, T.W. (2002). SWOT (Strenght T'Veaknesses Opportunity Threats) : Analysis Tools For Strategy Formulation. LaboratorySistim and Optimization of Fisheries Capture Department of Utilization Sumbcrdaya Fisheries Faculty of Fisheries and Marine Sciences Lnsitut Agriculture Bogor.

[8] Rahmalia, E. (2003). Study of Coastal And Ocean Resource Management. Post-graduate Program of Bogor Agricultural Institute. Bogor.

[9] Syafrin. (1993). Analysis of Factors Affecting Padang Municipal Income). Thesis. IPB-UNAND. Padang Arrest lkan (Case Study in the City
[10] yahza, A. (2003). Design of Rural Community Economic Empowerment Model Based on Agribusiness in Dacrah Riau. Jumal Rural Development Vol 3 Number 2, August-November 2003. ISSN 1411-9250.

[11] alakua. E. (2006). Optimization and Simulation of Pole and Line (Huhate) Fishery Business Production Factors in Ambon City. Thesis. Faculty of Fisheries and Marine Sciences Pattimura University. Ambon.

[12] Agung, Pasay, and Sugiarto, S. 2008. Microeconomic Theory, An Analysis of ProductionApplied. Publisher of PT RajaGrafindo Persada, Jakarta.

[13] Apridar. 2010. Marine Economy, First Edition, First Printing. Publisher of Graha Ilmu, Yogyakarta.

[14] Dahuri, R., J. Rais, S.P.Ginting and M.J.Sitepu. 2001. Integrated Management of Coastal and Marine Resources. Publisher of PT Pradya Paramitha, Jakarta.

[15] Maluku Marine and Fisheries Service. 2008. Annual Report of the Marine Service and The Ministry of Agriculture in 2008.

\section{AUTHORS}

First Author - Firmansyah, Department of Fisheries, F Marine Science and Fisheries Hasanuddin University Makassar

Second Author - Mardiana E. Fachry, Department of Fisheries, F Marine Science and Fisheries Hasanuddin University Makassar Third Author - Andi Adri Arief, Department of Fisheries, F Marine Science and Fisheries Hasanuddin University Makassar 